\title{
Physiological Role of Humic Acid, Amino Acids and Nitrogen Fertilizer on Growth of Wheat under Reclaimed Sandy Soil
}

\author{
Ahmed A. Kandil ${ }^{1}$, Ali. E.M. Sharief ${ }^{1 *}$, Saleh E. Seadh ${ }^{1}$, Dhurgham S.K Altai ${ }^{2}$ \\ ${ }^{1}$ Department of Agronomy, Faculty of Agriculture, Mansoura University, Egypt \\ *Corresponding Author: Prof. Ali Sharief Agronomy Dept., Fac. of Agric., Mansoura University, Egypt, 35516 El- \\ Mansoura, Egypt \\ ${ }^{2}$ Agronomy Department, Faculty of Agriculture, Basrah University, Iraq.
}

\begin{abstract}
In order to evaluate productivity of some wheat cultivars grown in sandy, saline soil under foliar spraying with humic acid, amino acids and nitrogen fertilizer levels. Highest chlorophyll $b$ and carotenoid content, percentage of sodium and calcium, tallest plants and higher number of tillers/plant were achieved from Gemiza 9 cultivar. The highest relative growth rate $(R G R)$ and net assimilation rate (NAR), chlorophyll and total chlorophyll values, higher flag leaf area and stem diameter were resulted from Giza 168 cultivar. While, higher percentages of proline, total phenols and potassium percentages were found from Shaka 93 cultivar. The earlier for a number of days to heading and flowering were resulted from Shaka 93 cultivar. Application of humic and amino acid mixture significantly enhanced total leaf area/plant, plant dry weight after 75 and 95 days from sowing (DFS), RGR, NAR, photosynthetic pigments, i.e. chlorophyll a, chlorophyll b and carotenoids and proline contents. In addition, highest total phenols, potassium and calcium percentages, height flag leaf area, tallest plants, highest stem diameter and number of tillers/plant compared with other foliar spraying treatments. Accordingly, it could be recommended that foliar spraying wheat plants Giza 168 cultivar with the mixture of humic acid and Amino acids with addition, mineral fertilizing with $262 \mathrm{~kg} \mathrm{~N} / \mathrm{ha}$ to obtain the best growth characters of wheat under newly reclaimed sandy saline soil conditions.
\end{abstract}

Keywords - Wheat Cultivars, Humic Acid, Amino Acids, Nitrogen Fertilizer levels.

\section{INTRODUCTION}

There is a huge shortage in production of wheat in Egypt, it imported more than $50 \%$ of our consumption [1]. The extreme increase in population in Egypt needs to increase wheat production in order to overcome this lack in production through its cultivation in the new reclaimed soils especially under saline conditions of such soil. To increase the cultivated area of wheat plant it is necessary to go to newly reclaim soils. However, most of the newly reclaimed soil suffers from salinity problem. Salinity is a major abiotic stresses in arid and semi-arid regions that sustained decreases the yield of major crops by more than $50 \%$. Considerate the influences between a plant's initial response and the downstream events that establish a successful adjustment to its altered environment is one of the next grand challenges of plant biology [2]. Salinity restrictions, soil fertility in irrigated regions of the world, this effect due to low rainfall in these areas besides soil leaching does not occur [3]. Soils contain soluble salts of multifarious nature, when soil and environmental conditions allow the concentrations in soil profiles to a high level, soil salinity becomes a severe threat to land degradation and crop productivity [4]. According to FAO about 20 to 30 million hectares of irrigated land are currently seriously damaged by salinity, and 0.25 to 0.50 million hectares are lost from production every year as a result of salt accumulation. So, it could be achieved through using suitable agronomic practices. Chosen the high yielding ability cultivars undoubtedly is very important to raise wheat productivity per unit area. For this reason, this study is aimed to evaluate the new promising cultivars for scooping light on the best cultivar that can be used under the environmental conditions of newly reclaimed sandy saline soils. Gemmiza 7 cultivar at the three stages (75, 96 and 117 days after sowing) of growth produced tallest plants, number of tillers/plant, dry weight/plant, leaf area/plant and flag leaf area and also crop growth rate (CGR) and relative growth rate (RGR) at growth intervals of 96-117 days after sowing than Sakha 93 cultivar [5]. The largest flag leaf area was obtained from Sakha 93 and Gemmeiza 9 cultivars. Though, Sakha 94 cultivar significantly exceeded all studied cultivars in plant height [6]. Sohag-3 cultivar produced tallest plants. While, BaniSweef-3 recorded the highest number of tillers/plant. Whereas, Sohag-2 recorded highest leaves area/plant [7]. Total phenols increased in Sakha 93 cultivar as compared with those of Gemiza 9 cultivar 
grown under salinity stress [8]. Gemmiza 10 cultivar exceeded (Gemmiza 9 and Sakha 93) cultivars in number of days to heading, flag leaf area and plant height [9].

Foliar fertilization is a widely used practice to correct nutritional deficiencies in plants caused by improper supply of nutrients to the roots. Foliar application stimulates the plants to create exudates in the roots which excite microbes to work harder and thus increases nutrient uptake from the soil. Sprayings are a great supplement to boost flavors, sweetness, mineral density and yield of crops [10]. Humic acid is a principal component of humic substances, which are the major organic constituents of soil (humus). Humic substances have many beneficial effects on soil physical structure and soil microbial populations as well as increase, modify mechanisms involved in plant growth stimulation, cell permeability and nutrient uptake and increasing yield $[11,12]$. Humic acid foliar spraying significantly increased photosynthesis process and antioxidant metabolism under water stress conditions [13]. Humic acid foliar spraying significantly affected dry weight and the uptake of mineral elements. Dry weight was higher in humic acid spraying when compared with the control treatment. The highest dry weight was obtained from $0.1 \%$ dose of humic acid [14]. Foliar spraying with humic acid significantly increased plant height $[2,15]$.

Amino acids enhanced chlorophyll concentration leading to higher degrees of photosynthesis, which makes crops lush. Amino Acids act as a cytoplasm osmotic agent on stomata cell, which help plants improve absorption of macro and trace nutrients as well as gasses through favoring the opening of stomata. It helps the absorption and transportation of micronutrients inside the plant getting easier. Also, it actions as equilibrium of soil microbial flora to improve mineralization of the organic matter and formation of a good soil structure and fertility around the roots [16]. Applied of nitrogen to the plant will affect the amount of protein, protoplasm and chlorophyll formed. In turn, this influences cell size, leaf area and photosynthetic activity. Availability of nitrogen increased tiller number, the number and weight of the grains, consequently yields of wheat [17]. Nitrogen fertilizer has a good effect on plant productivity, nevertheless it's also having a polluting effect on the environment. Increasing nitrogen fertilizer up to $90 \mathrm{~kg} \mathrm{~N} /$ fed significantly exceeded other levels in photosynthetic pigments, growth characters, yield components, yield and quality characters [18]. Increasing nitrogen fertilizer level up to $100 \mathrm{~kg}$ $\mathrm{N} /$ fed significantly increased flag leaf area, plant height, spike length, grain and straw yields/fed and protein content of grains [19]. Plants grown-up under the control treatment produced significantly lesser of total dry matter than those treated with 90,120 and $150 \mathrm{~kg} \mathrm{~N} / \mathrm{ha}$
[20,21]. Increasing nitrogen fertilization rates up to 80 or $120 \mathrm{~kg} \mathrm{~N} / \mathrm{ha}$ significantly increased number tillers/plant and spike length. High and economical increases of study parameters was $80 \mathrm{~kg} \mathrm{~N} / \mathrm{ha}$, which gave the highest number of tillers/plant and spike length. Maximum grain yield resulted from the application of $100 \mathrm{~kg} \mathrm{~N} / \mathrm{ha}$ [22]. Therefore, this study was aimed to decide the effect of foliar application with humic acid, amino acid under nitrogen fertilizer levels on the growth, yield and its attributes and chemical constituents of some cultivars of bread wheat grown in newly reclaimed sandy saline soil conditions in conditions.

\section{MATERIALS AND METHODS}

\subsection{Research time and location:}

Two field experiments were conducted at Station Farm of Kalabsho and Zayan district, Faculty of Agriculture, Mansoura University, Egypt. The experiments were set to find response of wheat cultivars (Shaka 93, Gemiza 9 and Giza 168) to foliar spraying (Spraying with water, spraying with Actosol source of humic acid at the rate of $5 \mathrm{ml} /$ liter water, spraying with Amino-Cat source of amino acids at the rate of $5 \mathrm{ml} /$ liter water and spraying with the mixture of Actosol and Amino-Cat at the rates of $5+5 /$ liter water, respectively) and nitrogen fertilizer levels $(166,214$ and $262 \mathrm{~kg} \mathrm{~N} / \mathrm{ha}$ as ammonium nitrate $33.5 \% \mathrm{~N})$.

The experimental soil was sandy in texture, $\mathrm{pH}$ was 8.5, E.C. was $9.11 \mathrm{dSm}^{-1}$, available nitrogen was $4.1 \mathrm{ppm}$, available phosphorus was $5.53 \mathrm{ppm}$ and organic matter was $0.65 \%$. Each experimental unit area was $3 \times 3.5 \mathrm{~m}$ occupying an area of $10.5 \mathrm{~m}^{2}$. A split-split plot design with three replicates was followed. Wheat cultivars were assigned to the main plots, whereas foliar spraying and nitrogen fertilizer were allocated in the $1^{\text {st }}$ and $2^{\text {nd }}$ order sub plots, respectively. Each experiment included thirtysix treatments comprising, three wheat cultivars, four foliar spraying and three nitrogen fertilizer levels. The foliar solution volume was 475 liter/ha and spraying was conducted by hand sprayer (for experimental plots) until saturation point three times after 30, 45 and 60 days from sowing. Tween-20 was used as a wetting agent at $0.02 \%$ concentration. While, Nitrogen fertilizer was applied at the aforementioned levels as a side-dressing in four equal doses prior every irrigation and finished before heading. All plants received full irrigation and maintained weed free by hand weeding after sowing whenever necessary. Phosphorus fertilizer was applied during soil preparation as calcium super phosphate $\left(15.5 \% \quad \mathrm{P}_{2} \mathrm{O}_{5}\right)$ at the rate of $476 \mathrm{~kg} / \mathrm{ha}$. Potassium fertilizer was broadcasted in one dose before the second irrigation as potassium sulphate $\left(48 \% \mathrm{~K}_{2} \mathrm{O}\right)$ at the rate of $178 \mathrm{~kg} / \mathrm{ha}$. Grains of wheat 
cultivars were sown at the rate of $190 \mathrm{~kg} / \mathrm{ha}$, during the last week of November by using hand drilling in both seasons. Plants were harvested on $5^{\text {th }}$ and $9^{\text {th }}$ of May for growing seasons.

\subsection{Studies characters:}

At the emergence of approximately 50\% spikes/plot and $50 \%$ flowering approximately of the spikes/plot, it was calculated the number of days to $50 \%$ heading and number of days to $50 \%$ flowering, respectively. At 75 and 95 days after sowing samples were taken for determination total leaf area/plant $\left(\mathrm{cm}^{2}\right)$ : Determined according to [23]. The dry weight of plant (g): All plant fractions were air-dried, then oven dried at $70^{\circ} \mathrm{C}$ till constant weight obtained. 3-Crop growth rate (CGR): Determined according to [24]. 4-Relative growth rate (RGR): Determined according to [24]. 5-Net assimilation rate (NAR): Determined according to [25]. Samples of flag leaf were taken after 90 days from sowing for the following chemical analysis. 6-Photosynthetic pigments: Both chlorophyll and carotenoid contents in fresh leaves were estimated using the method of [26]. 7-Proline content: Proline content was determined in flag leaf by the modification of ninhydrine method of [27]. 8-Total Phenols: Total Phenols was assayed according to the method described by [28]. 9-Sodium and potassium percentages: Sodium and potassium percentages were estimated by using flame photometer according to [29]. 10-Calcium percentage: Calcium percentage was determined by using the atomic absorption spectrophotometer as a method of [30] After 125 days from sowing, where five guarded plants were chosen from each sub-plot to determine 6-Flag leaf area $\left(\mathrm{cm}^{2}\right)$ : Calculated according to [23]. 7-Plant height (cm). 8-Stem diameter (mm). 9-Number of tillers/plant.

\subsection{Experimental analysis:}

All obtained data were statistically analyzed according to the technique of analysis of variance (ANOVA) for the split - plot design to each experiment (row spacing), then combined analysis was done between row spacing trails as published by [31] by using "MSTAT-C" computer software package. A Least significant of the difference (LSD) method was used to test the differences between treatment means at the $5 \%$ level of probability as described by [32].

\section{RESULTS AND DISCUSSION}

\subsection{Cultivars Performance:}

Results presented in Tables 1, 2 and 3, the results clearly showed that there were significant differences in most the growth, physiological and chemical characters among wheat cultivars in the two growing seasons. Under conditions of this study, Gemiza 9 cultivar caused a significant increase in characters, i.e. chlorophyll b, carotenoids, sodium, calcium percentages, plant height (cm) and number of tillers/plant in both seasons. The highest values of relative growth rate $(\mathrm{g} / \mathrm{g} / \mathrm{week})$, net assimilation rate $\left(\mathrm{g} / \mathrm{m}^{2} /\right.$ week), chlorophyll a $(\mathrm{mg} / \mathrm{g}$ fresh weight), total chlorophylls ( $\mathrm{mg} / \mathrm{g}$ fresh weight), flag leaf area $\left(\mathrm{cm}^{2}\right)$ and stem diameter $(\mathrm{cm})$ were resulted from Giza 168 cultivar. Whereas, the highest values of proline (mg/g fresh weight), total phenols (mg/100 $\mathrm{g}$ fresh weight) and potassium percentages were obtained from Shaka 93 cultivar. From obtained results, earliness characters (numbers of days to $50 \%$ heading and numbers of days to $50 \%$ flowering) significantly affected by different wheat cultivars. The earlier in heading and flowering were resulted from Shaka 93 cultivar in the first and the second seasons, respectively. The variation among wheat cultivars may be due to the genetically variation among them as a result of the differences of wheat cultivars pedigree (Table 1). Similar results were obtained by $[5,6,7,8,9]$.

\subsection{Effect of foliar spraying treatments:}

Foliar spraying treatments using from humic acid, amino acids and the mixture of humic and amino acids were associated significant effect on most growth, physiological and chemical characters in both seasons (Tables 1, 2 and 3). Foliar spraying with a mixture of humic and amino acids significantly improved most characters and induced the highest values of total leaf area/plant $\left(\mathrm{cm}^{2}\right)$, plant dry weight $(\mathrm{g})$ after 75 and 95 DFS, relative growth rate $(\mathrm{g} / \mathrm{g} /$ week), net assimilation rate $\left(\mathrm{g} / \mathrm{m}^{2} /\right.$ week), flag leaf area $\left(\mathrm{cm}^{2}\right)$, plant height $(\mathrm{cm})$, stem diameter $(\mathrm{cm})$ and number of tillers/plant. These findings associated with increasing of photosynthetic pigments (chlorophyll a, chlorophyll $\mathrm{b}$ and carotenoids $\mathrm{mg} / \mathrm{g}$ fresh weight), Proline content (mg/g fresh weight), total Phenols (mg/100 g fresh weight), potassiumpercentage, calcium percentage and decrease of sodium percentage of wheat plants compared with other foliar spraying treatments (humic acid or amino acids) and spraying with water (control treatment) in both seasons. From obtained results, earliness characters (numbers of days to $50 \%$ heading and $50 \%$ flowering) significantly affected by foliar spraying treatments in both seasons. Foliar spraying wheat plants with the mixture of humic acid and amino acids significantly surpassed other foliar spraying treatments (humic acid or amino acids) and spraying with water (control treatment) and produced the highest values in the first and second seasons. This increase in attributes under study by foliar spraying treatments with nutrient compounds that contains macro and micronutrients may be due to the role of macro and micronutrients in increasing meristematic activity and production of some growth regulators such as Indole Acetic Acid (IAA), which is essential for the elongation of the internodes 
reflecting increases in these traits. These findings were proportionately with those reported by $[12,14,15]$.

\subsection{Effect of nitrogen fertilizer levels:}

With respect to the effect of nitrogen fertilizer levels on most growth, physiological and chemical characters in both seasons (Tables 1,2 and 3). The results clearly indicated that a significant in the two growing seasons of these characters as shown in Tables 1,2 and 3. All studied characters of wheat plants gradually increased as a result of increasing nitrogen fertilizer levels from 166 to 214 and $262 \mathrm{~kg} \mathrm{~N} / \mathrm{ha}$ in both seasons, it was evident that, under the environmental conditions of newly reclaimed sandy, saline soil, wheat plants still responded to more levels of nitrogen fertilizer up to $262 \mathrm{~kg} \mathrm{~N} / \mathrm{ha}$. Generally, maximum means of all studied characters were produced from fertilizing wheat plants with $262 \mathrm{~kg}$ N/ha in the first and second seasons. On the contrary, the lowest values of these characters were obtained from plots that received lowest nitrogen fertilizer levels (166 kg N/ha). This increase in wheat growth characters due to increasing nitrogen fertilizer levels might have been due to nitrogen, which considers as one of the major elements which is essential for plant growth, and plays an important role as division and elongation of cells are concerned, thus increasing cell number and size and also via activation metabolic and photosynthesis processes. Similar results were obtained by $[18,18,20,21,22]$.

\section{4- Effect of interactions:}

Regarding the effect of interactions, there are many significant effects of the interactions on the studied characters. We present only the effect of significant interactions on the studied characters in both seasons (Tables 1, 2 and 3). Means of relative growth rate (RGR) were insignificantly affected by various interactions among studies factors, i.e. cultivars, foliar spraying and nitrogen fertilizer levels in both seasons, except the interaction between cultivars $\times$ nitrogen fertilizer levels in the first season and foliar spraying $\times$ nitrogen fertilizer levels in both seasons (Table 2). The results graphically illustrated in Fig.1 showed that foliar spraying with humic and amino acids in mixture and increasing nitrogen fertilizer levels up to $262 \mathrm{~kg}$ N/ha significantly recorded highest relative growth rate (RGR). The interaction among wheat cultivars, foliar spraying treatments and nitrogen fertilizer levels had a significant effect on the total chlorophylls percentage in flag leaf in both seasons, except the interaction between cultivars $\times$ foliar spraying treatments, cultivars $\times$ nitrogen fertilizer levels (in the second season) and foliar spraying treatments $\times$ nitrogen fertilizer levels (in the first season). The results graphically illustrated in Figs. 2 showed that foliar spraying Giza 168 cultivar with humic and amino acids in mixtures and increasing nitrogen fertilizer levels up to
$262 \mathrm{~kg} \mathrm{~N} / \mathrm{ha}$ significantly recorded highest total chlorophylls percentage in flag leaf in both seasons. However, the lowest total chlorophylls percentage in flag leaf was produced fertilizing Sakha 93 cultivar with 166 $\mathrm{kg} \mathrm{N} /$ ha without foliar spraying (control treatment).

\section{CONCLUSION}

Accordingly, it can be recommended that foliar spraying wheat plants Giza 168 cultivar with the mixture of humic acid and Amino acids with addition, mineral fertilizing with $262 \mathrm{~kg} \mathrm{~N} / \mathrm{ha}$ to obtain the best growth characters of wheat under newly reclaimed sandy saline soil conditions.

\section{REFERENCES}

[1] A.G. Salam, "Current status of durum wheat in Egypt and Future prospects, 2002. http:// www. Fineprint.com.

http://scialert.net/abstract/?doi=pjbs.2001.388.391

[2] [2] SM. El-Bassiouny, BA Bakry, AA Amany and MM Abd Allah, "Physiological role of humic acid and nicotinamide on improving plant growth, yield, and mineral nutrient of wheat (Triticum durum) grown under newly reclaimed sandy soil" Agric. Sci., 2014, 5: 687-700.

https://www.s cirp.org/journal/PaperInformation.as px?PaperID=48012

[3] D.L. Corwin, JD Rhoades and PJ Vaughan, "GIS apply the basin-scale assessment of soil salinity and salt in groundwater. SSSA Special Publication No. 48, Soil Science Society of America, 1996, Madison, WI. 295-313. https ://www.ars .usda.gov/ars userfiles/20360500/p df_pubs/P1412.pdf

[4] R. Munnus, "Comparative physiology of salt and water stress. Plant Cell Environ., 2002, 25: 239250.

http://www.scirp.org/(S(351jmbntvnsjt1aadkposzj

e))/reference/References Papers .as px?ReferenceID $=1878544$

[5] MA. Goma, NM. Zaki, FI. Radwan, MS. Hassanein, AM. Gomaa and AM. Wali, "The combined effect of mineral, organic and biofertilizers on growth of some wheat cultivars. J. of Appl. Sci. Res., 2011, 7(11): 1591-1608. http://www.aensiweb.com/old/jasr/jasr/2011/15911608.pdf

[6] A. El-Metwally, NA. Khalil, MM. El-Fouly and MF. El-Dahshouri, "Growth, nutrients uptake and grain yield of some wheat cultivars as affected by zinc application under sandy soil conditions" J. Plant Production, Mansoura Univ., 2012, 3(5): 773 
783. http://agrfac.mans.edu.eg/en/projects research/scientific-journal

[7] MM. Hussein and NF. Abd El Hady, "Growth and photosynthetic pigments responses of durum wheat varieties to irrigation by diluted sea water. International Journal of Science and Research, 2012, 3(12): $1656-1663$. http://www.ijsr.net/archive/v3i12/U1VCMTQ1M $\mathrm{Dc}=. \mathrm{pdf}$

[8] RE. Safaa, TA. Magdi and F. Reda, "Effect of potassium application on wheat (Triticum aestivum L.) cultivars grown under salinity stress. World App. Sci. J., 2013, 26 (7): 840-850.

https://www.academia.edu/6798330/Effect_of_Pot assium_Application_on_Wheat_Triticum_aestivu m_L._Cultivars_Grown_Under_Salinity_Stress

[9] MH. Hendawey, "Biochemical changes as sociated with induction of salt tolerance in wheat. Global $\mathrm{J}$. of Biotech. and Biochem., 2015, 10 (2): 84-99. https://www.idosi.org/gjbb/gjbb10(2)15/5.pdf

[10] HH. Hsu, "Chelates in plant nutrition" In: Foliar feeding of plants with amino acid chelates, Ashmead, H.D.; H.H. Ashmead; G.W. Miller and H.H. Hsu, Noyes Publications, Park Ridge, New Jersey, 1986, USA, pp 209-217.

https://www.cabdirect.org/cabdirect/abstract/1986 1909248

[11] KM. Cimrin and I. Yilmaz, "Humic acid applications to lettuce do not improve yield but do improve phosphorus availability" Acta Agric. Scandinavica, Section B, Soil and Plant Sci., 2005, 55:

$58-63$.

http://www.tandfonline.com/doi/full/10.1080/0906 4710510008559? s croll=top \&need Acces $s=$ true

[12] BB. Asik, MA. Turan, H. Celik and AV. Katkat, "Effects of humic substances on plant growth and mineral nutrients uptake of wheat (Triticum durum cv. Salihli) under conditions of salinity" Asian J. Crop Sci., 2009, 1(2), 87-95. http://scialert.net/abstract/?doi=ajcs .2009 .87 .95

[13] C. Fujiu, Y. Daoqi and Wu. Qingsheng, "Physiological effects of humic acid on drought resistance of wheat (in Chinese), " Yingyong Shengtai Xuebao 6, 1995, 363-367. http://agris .fao.org/agris search/s earch.do?recordID=CN9611622

[14] AV. Katkat, H Celik, MA Turan and BB Asik, "Effects of soil and foliar applications of humic substances on dry weight and mineral nutrients uptake of wheat under calcareous soil conditions" Aust. J. Basic and Appl. Sci., 2009, 3(2), 1266$1273 . \quad$ http://isplb03aux3.semantico.net/abstracts/20093184081.html
[15] SH. Abbas, M. Sohail, I. Hussain, M. Saleem, M. Qamar, M Aslam and M. Imran, "Grain yield of newly developed wheat cultivar (narc 2011) as enhanced by foliar application of humic acid under rainfed conditions" Sarhad J. Agric., 2014, 30(2), 173-178.

http://175.107.15.226:8080/jspui/browse?type=aut hor\&order $=\mathrm{ASC} \& \mathrm{rpp}=20 \&$ value $=\mathrm{Abbas} \% 2 \mathrm{C}+\mathrm{S} . \mathrm{H}$

[16] HD. Ashmead, "The absorption mechanism of amino acid chelates by plant cells. In: Foliar feeding of plants with amino acid chelates" Ashmead, H.D., H.H. Ashmead, G.W. Miller and H.H. Hsu (Ed.), Noyes Publications, Park Ridge, New Jersey, 1986, USA, pp 219-235.

[17] S. Delfine, R. Tognetti, E Desiderio and A. Alvinoa, "Effect of foliar application of $\mathrm{N}$ and humic acids on growth and yield of durum wheat" Agron. Sustain. Dev., 2005, 25, 183-191. https://hal.archives-ouvertes .fr/hal00886291/document

[18] SE. Seadh, MI. EL-Abady, S. Farouk and A. ELSaidy, "Effect of foliar nutrition with humic and amino acids under $\mathrm{N}-$ levels on wheat productivity and quality of grains and seed" Egypt. J. of Appl. Sci., 2008, $23 \quad(12 \quad$ B): 543-558. https://scholar.google.com/citations ?user=Nay ZBAAAAAJ\&hl=en

[19] LW. Antoun, MZ. Sahar and HR. Hanaa, "Influence of compost, N-mineral and humic acid on yield and chemical composition of wheat plants" J. Soil Sci. and Agric. Engi., Mansoura Univ. 2010, 1(11), 1131- 1143. http://www.eulc.edu.eg/eulc_v5/Libraries/UploadF iles/DownLoadFile.aspx?RelatedBibID=ZDk1ZDI wNzktNTZiZC00OTgxLThiNGYtNGE3ODUyZG U4ZmVhX210ZW 1zXzEyMTE3NzU1XzExNzg4 MjY0X18=\&filename $=1131-1143$.pdf

[20] R. Ali, "Effect of planting date and nitrogen on growth and morphological traits of dry land wheat in Yasooj region of Iran" Annals of Biological Research, 2012, 3 (7), 3263-3266. http://www.scholars researchlibrary.com/

[21] M.Z. Rahman, M.R. Islam, M.T. Islam and M.A. Karim, "Dry matter accumulation, leaf area index and yield responses of wheat under Different Levels of Nitrogen" Bangladesh J. Agric., 2014, $7(1)$, 27-32. https://www.researchgate.net/publication/2688181 40_Dry_Matter_Accumulation_Leaf_Area_Index_ and_Yield_Responses_of_Wheat_under_Different _Levels_of_Nitrogen 
[22] S.M. Shirazi, Z. Yusop, N.H. Zardari and Z. Is mail, "Effect of irrigation regimes and nitrogen levels on the growth and yield of wheat. Advances in Agric., 2014, Article ID 250874 1-6. https://www.hindawi.com/journals/aag/2014/2508 $74 /$

[23] F.P. Gardner, RB Pearce and RL. Michell, "Physiology of crop plant. Iowa State Univ. Press Ames. Iowa, 1985, USA pp. 58-75. ISBN-13: 9780813813769

[24] P.J. Radford, "Growth analysis formulae-their use and abuses" Crop Sci.,1967, 7, 171-175. http://garfield.library.upenn.edu/clas sics 1981/A19 81LS97200001.pdf

[25] D.J. Watson, "The physiological basis of variation yield" Adv. in Agron,1952, 4, 101-145. http://www.oalib.com/references/14435774

[26] H.K. Lichtenthaler and C. Buschmann, "Chlorophylls and Carotenoids: Measurement and Characterization" by UV-VIS Spectroscopy. In: Wrolstad, R.E., Acree, T.E., An, H., Decker, E.A., Pinner, M.H., Reid, D.S., Schwartz, S.J., Shoemaker, C.F. and Sporns, P., Eds., Current Protocols in Food Analytical Chemistry, John Wiley and Sons, New York, 2001, F4.3.1-F4.3.8. http://www.scirp.org/(S(vtj3fa45qm1ean45vvffcz5 5))/reference/References Papers.aspx?ReferenceID $=1698995$
[27] W. Troll and J. Lindsky, "A photometric method for the determination of proline" J. Biol. Chem., 1955, 215, 655-660.

https://www.ncbi.nlm.nih.gov/pubmed/13242563

[28] H.D. Daniel and CM. George, "Peach seed dormancy in relation to endogenous inhibitors and applied growth substances" J. Am. Soc. Hortic. Sci., $\quad$ 1972, $\quad$ 97: 651-654. http://www.sphinxsai.com/2016/ch_vo19_no9/1/(1 24-131)V9N9CT.xml

[29] A.V. Peterburgski "Hand Book of Agronomic Chemistry" Kolas publishing House, Moscow, (in Russian), 1986, pp. 29-86.

[30] H.D. Chapman and PF. Pratt, "Methods of analysis for soils, plants and waters. Division of Agricultural Sciences,1961, University of California,

Riverside. http://www.sciepub.com/reference/37837

[31] KA Gomez and AA. Gomez, "Statistical Procedures for Agricultural Research". 2 ${ }^{\text {nd }}$ Ed., John Wiley and Sons Inc., 1991, New York, pp: 95-109. ISBN-13: 978-0471870920

[32] Snedecor GW, Cochran WG. 1980. "Statistical Methods" 7th Ed. The Iowa State Univ. Press, Iowa, USA. https://www.amazon.com/StatisticalMethods-Seventh-isbn0813815606/dp/B0012S4NIE

Table.1: Total leaf area/plant, plant dry weight, crop growth rate, relative growth rate and net assimilation rate as affected by foliar spraying and nitrogen fertilizer levels of some wheat cultivars as well as their interactions during

2013/2014 and 2014/2015 seasons.

\begin{tabular}{|c|c|c|c|c|c|c|c|c|c|c|c|c|c|c|}
\hline \multirow{3}{*}{$\begin{array}{l}\text { Characters } \\
\text { Treatments }\end{array}$} & \multicolumn{4}{|c|}{ Total leafarea/plant $\left(\mathrm{cm}^{2}\right)$} & \multicolumn{4}{|c|}{ Plant dry weight (g) } & \multicolumn{2}{|c|}{$\begin{array}{l}\text { CGR } \\
\text { (g/week) }\end{array}$} & \multicolumn{2}{|c|}{$\begin{array}{l}R G R \\
(g / g / \text { week })\end{array}$} & \multicolumn{2}{|c|}{$\begin{array}{l}\text { NAR } \\
\left(\mathrm{g} / \mathrm{m}^{2} / \text { week }\right)\end{array}$} \\
\hline & $\begin{array}{l}75 \\
\text { DFS }\end{array}$ & $\begin{array}{l}95 \\
\text { DFS }\end{array}$ & $\begin{array}{l}75 \\
\text { DFS } \\
\end{array}$ & $\begin{array}{l}95 \\
\text { DFS } \\
\end{array}$ & $\begin{array}{l}75 \\
\text { DFS } \\
\end{array}$ & $\begin{array}{l}95 \\
\text { DFS } \\
\end{array}$ & $\begin{array}{l}75 \\
\text { DFS } \\
\end{array}$ & $\begin{array}{l}95 \\
\text { DFS } \\
\end{array}$ & \multirow{2}{*}{$\begin{array}{l}2013 \\
/ 2014\end{array}$} & \multirow{2}{*}{$\begin{array}{l}2014 \\
/ 2015\end{array}$} & \multirow{2}{*}{$\begin{array}{l}2013 \\
/ 2014\end{array}$} & \multirow{2}{*}{$\begin{array}{l}2014 \\
/ 2015\end{array}$} & \multirow{2}{*}{$\begin{array}{l}2013 \\
/ 2014\end{array}$} & \multirow{2}{*}{$\begin{array}{l}2014 \\
/ 2015\end{array}$} \\
\hline & $\begin{array}{l}2013 \\
/ 2014\end{array}$ & $\begin{array}{l}2014 \\
/ 2015\end{array}$ & $\begin{array}{l}2013 \\
/ 2014\end{array}$ & $\begin{array}{l}2014 \\
/ 2015\end{array}$ & $\begin{array}{l}2013 \\
/ 2014\end{array}$ & $\begin{array}{l}2014 \\
/ 2015\end{array}$ & $\begin{array}{l}2013 \\
/ 2014\end{array}$ & $\begin{array}{l}2014 \\
/ 2015\end{array}$ & & & & & & \\
\hline \multicolumn{15}{|l|}{ A-Cultivars: } \\
\hline Shaka93 & 212.4 & 216.0 & 238.7 & 243.2 & 6.05 & 6.28 & 11.36 & 11.82 & 1.86 & 1.93 & 0.18 & 0.18 & 10.73 & 10.82 \\
\hline Gemiza 9 & 238.8 & 248.6 & 270.1 & 281.3 & 7.85 & 8.67 & 13.21 & 14.29 & 1.87 & 1.96 & 0.20 & 0.19 & 12.21 & 12.22 \\
\hline Giza 168 & 213.3 & 216.1 & 246.0 & 251.8 & 7.43 & 7.80 & 12.88 & 13.36 & 1.90 & 1.94 & 0.23 & 0.22 & 12.22 & 12.74 \\
\hline F. test & $*$ & $*$ & $*$ & $*$ & $*$ & $*$ & $*$ & $*$ & NS & NS & $*$ & $*$ & NS & $*$ \\
\hline LSD at $5 \%$ & 9.5 & 9.6 & 10.6 & 10.1 & 0.47 & 0.30 & 0.80 & 0.78 & - & - & 0.02 & 0.02 & - & 0.68 \\
\hline \multicolumn{15}{|c|}{ B-Foliar spraying: } \\
\hline $\begin{array}{l}\text { Control } \\
\text { treatment }\end{array}$ & 183.5 & 189.3 & 209.3 & 215.6 & 6.28 & 6.82 & 11.70 & 12.50 & 1.89 & 1.98 & 0.19 & 0.18 & 9.65 & 9.43 \\
\hline $\begin{array}{l}\text { Humic acid } \\
\text { (HA) }\end{array}$ & 207.3 & 212.2 & 237.5 & 246.0 & 6.72 & 7.36 & 12.16 & 13.05 & 1.90 & 1.99 & 0.21 & 0.20 & 12.37 & 12.56 \\
\hline $\begin{array}{l}\text { Amino acids } \\
\text { (AA) }\end{array}$ & 231.0 & 233.0 & 262.0 & 265.2 & 7.49 & 7.70 & 12.77 & 13.15 & 1.84 & 1.90 & 0.19 & 0.19 & 10.90 & 11.47 \\
\hline $\begin{array}{l}\text { Mixture of } \\
\text { HA + AA }\end{array}$ & 264.4 & 273.2 & 297.7 & 308.3 & 7.94 & 8.45 & 13.31 & 13.90 & 1.87 & 1.90 & 0.22 & 0.21 & 13.96 & 14.24 \\
\hline F. test & $*$ & $*$ & $*$ & $*$ & $*$ & $*$ & $*$ & $*$ & NS & NS & NS & $*$ & $*$ & $*$ \\
\hline
\end{tabular}




\begin{tabular}{|l|l|l|l|l|l|l|l|l|l|l|l|l|l|l|l|l|}
\hline LSD at 5 \% & 15.6 & 15.6 & 15.7 & 16.2 & 1.13 & 1.01 & 1.00 & 1.08 & - & - & - & 0.02 & 1.23 & 1.51 \\
\hline C- Nitrogen fertilizer levels: \\
\hline $\mathbf{1 6 6}$ kg N/ha & 216.3 & 219.2 & 243.2 & 248.1 & 5.36 & 5.98 & 10.99 & 11.87 & 1.80 & 1.86 & 0.16 & 0.16 & 10.77 & 10.80 \\
\hline $\mathbf{2 1 4}$ kg N/ha & 218.2 & 224.9 & 248.0 & 256.5 & 6.82 & 7.41 & 12.16 & 12.89 & 1.86 & 1.92 & 0.20 & 0.19 & 11.73 & 11.73 \\
\hline $\mathbf{2 6 2}$ kg N/ha & 230.2 & 236.6 & 263.7 & 271.7 & 9.15 & 9.37 & 14.30 & 14.70 & 1.97 & 2.06 & 0.25 & 0.24 & 12.67 & 13.23 \\
\hline F. test & $*$ & $*$ & $*$ & $*$ & $*$ & $*$ & $*$ & $*$ & $*$ & $*$ & $*$ & $*$ & $*$ & $*$ \\
\hline LSD at 5 \% & 8.9 & 9.7 & 8.0 & 9.8 & 0.34 & 0.27 & 0.35 & 0.32 & 0.06 & 0.08 & 0.01 & 0.01 & 0.58 & 0.37 \\
\hline
\end{tabular}

Table.2: Chlorophyll a, chlorophyll b, total chlorophylls, carotenoids, proline percentage, total phenols, sodium percentage, potassium percentage and calcium percentage as affected by foliar spraying and nitrogen fertilizer levels of some wheat cultivars as well as their interactions during 2013/2014 and 2014/2015 seasons.

\begin{tabular}{|c|c|c|c|c|c|c|c|c|c|c|c|c|c|c|c|c|c|c|}
\hline \multirow[t]{2}{*}{$\begin{array}{l}\text { Characters } \\
\text { Treatments }\end{array}$} & \multicolumn{2}{|c|}{$\begin{array}{c}\text { Chlorophyll a } \\
\text { (mg/g fresh } \\
\text { weight })\end{array}$} & \multicolumn{2}{|c|}{$\begin{array}{c}\text { Chlorophyll b } \\
\text { (mg/g fresh } \\
\text { weight) }\end{array}$} & \multicolumn{2}{|c|}{$\begin{array}{c}\text { Total } \\
\text { chlorophylls } \\
\text { (mg/g fresh } \\
\text { weight }):\end{array}$} & \multicolumn{2}{|c|}{$\begin{array}{c}\text { Carotenoids } \\
\text { (mg/g fresh } \\
\text { weight })\end{array}$} & \multicolumn{2}{|c|}{$\begin{array}{c}\text { Proline } \\
\text { percentage } \\
\text { (mg/g fresh } \\
\text { weight) }\end{array}$} & \multicolumn{2}{|c|}{$\begin{array}{c}\text { Total phl. } \\
\text { (mg/100 g } \\
\text { fresh } \\
\text { weight })\end{array}$} & \multicolumn{2}{|c|}{$\mathrm{Na}(\%)$} & \multicolumn{2}{|c|}{$K(\%)$} & \multicolumn{2}{|c|}{$\mathrm{Ca}(\%)$} \\
\hline & $1^{s t}$ & $2^{n d}$ & $1^{s t}$ & $2^{n d}$ & $1^{s t}$ & $2^{\text {nd }}$ & $1^{s t}$ & $2^{\text {nd }}$ & $1^{s t}$ & $2^{\text {nd }}$ & $1^{s t}$ & $2^{\text {nd }}$ & $1^{s t}$ & $2^{n d}$ & $1^{s t}$ & $2^{n d}$ & $1^{s t}$ & $2^{\text {nd }}$ \\
\hline \multicolumn{19}{|l|}{$\begin{array}{c}A- \\
\text { Cultivars } \\
:\end{array}$} \\
\hline Shaka 93 & 0.780 & 1.144 & 0.367 & 0.439 & 1.146 & 1.583 & 0.439 & 0.494 & 14.22 & 15.21 & 95.68 & 96.44 & 0.092 & 0.101 & 2.192 & 2.392 & 0.313 & 0.323 \\
\hline Gemiza 9 & 0.778 & 1.056 & 0.472 & 0.520 & 1.251 & 1.576 & 0.611 & 0.684 & 12.41 & 13.61 & 93.49 & 95.46 & 0.107 & 0.116 & 1.870 & 2.070 & 0.248 & 0.298 \\
\hline Giza 168 & 1.026 & 1.151 & 0.422 & 0.488 & 1.448 & 1.639 & 0.430 & 0.485 & 13.07 & 14.47 & 93.92 & 95.95 & 0.099 & 0.109 & 2.025 & 2.225 & 0.254 & 0.304 \\
\hline F. test & $*$ & $*$ & $*$ & $N S$ & $*$ & $N S$ & $*$ & * & $*$ & * & $*$ & $N S$ & $*$ & $*$ & $*$ & $N S$ & $*$ & $*$ \\
\hline $\begin{array}{c}L S D \text { at } 5 \\
\%\end{array}$ & 0.073 & 0.074 & 0.067 & - & 0.127 & - & 0.060 & 0.050 & 0.40 & 0.58 & 1.40 & - & 0.011 & 0.006 & 0.054 & - & 0.004 & 0.007 \\
\hline \multicolumn{19}{|c|}{ B-Foliar spraying: } \\
\hline $\begin{array}{c}\text { Control } \\
\text { treatment }\end{array}$ & 0.806 & 0.939 & 0.387 & 0.453 & 1.205 & 1.393 & 0.411 & 0.455 & 11.15 & 12.67 & 91.45 & 93.84 & 0.133 & 0.143 & 1.310 & 1.510 & 0.335 & 0.372 \\
\hline $\begin{array}{c}\text { Humic } \\
\text { acid } \\
(\text { HA })\end{array}$ & 0.853 & 1.075 & 0.399 & 0.455 & 1.240 & 1.529 & 0.505 & 0.568 & 14.11 & 15.04 & 95.15 & 96.64 & 0.090 & 0.100 & 2.274 & 2.474 & 0.250 & 0.357 \\
\hline $\begin{array}{c}\text { Amino } \\
\text { acids } \\
(A A)\end{array}$ & 0.864 & 1.164 & 0.407 & 0.469 & 1.271 & 1.633 & 0.469 & 0.543 & 12.12 & 14.04 & 94.22 & 95.26 & 0.113 & 0.123 & 1.802 & 2.002 & 0.320 & 0.286 \\
\hline $\begin{array}{c}\text { Mixture } \\
\text { of } \boldsymbol{H A}+ \\
\boldsymbol{A A}\end{array}$ & 0.922 & 1.289 & 0.488 & 0.551 & 1.411 & 1.841 & 0.588 & 0.651 & 15.54 & 15.98 & 96.64 & 98.07 & 0.061 & 0.069 & 2.729 & 2.929 & 0.181 & 0.218 \\
\hline F. test & $*$ & $*$ & $*$ & * & $*$ & $*$ & * & $*$ & $*$ & $*$ & $*$ & $*$ & * & $*$ & $*$ & $*$ & $*$ & $*$ \\
\hline $\begin{array}{c}\text { LSD at } 5 \\
\%\end{array}$ & 0.011 & 0.010 & 0.011 & 0.009 & 0.011 & 0.009 & 0.002 & 0.001 & 0.93 & 0.79 & 0.98 & 0.86 & 0.020 & 0.015 & 0.189 & 0.152 & 0.023 & 0.030 \\
\hline \multicolumn{19}{|c|}{ C- Nitrogen fertilizer levels: } \\
\hline $\begin{array}{c}166 \mathrm{~kg} \\
\mathrm{~N} / \mathrm{ha}\end{array}$ & 0.830 & 1.080 & 0.387 & 0.449 & 1.217 & 1.529 & 0.462 & 0.523 & 13.11 & 14.45 & 94.25 & 95.75 & 0.090 & 0.099 & 1.931 & 2.131 & 0.275 & 0.312 \\
\hline $\begin{array}{c}214 \mathrm{~kg} \\
\mathrm{~N} / \mathrm{ha}\end{array}$ & 0.864 & 1.120 & 0.421 & 0.483 & 1.285 & 1.603 & 0.496 & 0.557 & 14.02 & 14.88 & 94.25 & 96.14 & 0.108 & 0.118 & 2.123 & 2.323 & 0.276 & 0.313 \\
\hline $\begin{array}{c}262 \mathrm{~kg} \\
\mathrm{~N} / \mathrm{ha}\end{array}$ & 0.890 & 1.151 & 0.453 & 0.515 & 1.343 & 1.666 & 0.521 & 0.583 & 12.57 & 13.96 & 94.59 & 95.96 & 0.101 & 0.109 & 2.033 & 2.232 & 0.263 & 0.300 \\
\hline F. test & $*$ & $*$ & $*$ & $*$ & $*$ & $*$ & $*$ & $*$ & $*$ & $*$ & $N S$ & $N S$ & $*$ & $*$ & $*$ & $*$ & $*$ & $*$ \\
\hline $\begin{array}{c}\text { LSD at } 5 \\
\%\end{array}$ & 0.007 & 0.005 & 0.005 & 0.005 & 0.006 & 0.005 & 0.001 & 0.001 & 0.36 & 0.43 & - & - & 0.005 & 0.004 & 0.065 & 0.077 & 0.009 & 0.010 \\
\hline
\end{tabular}




\section{D- Interactions:}

\begin{tabular}{|c|c|c|c|c|c|c|c|c|c|c|c|c|c|c|c|c|c|c|}
\hline$A \times B$ & $N S$ & $*$ & $N S$ & $*$ & $*$ & $N S$ & $N S$ & $*$ & $*$ & $N S$ & $*$ & $N S$ & $N S$ & $N S$ & $N S$ & $*$ & $*$ & $N S$ \\
\hline$A \times C$ & $N S$ & $*$ & $N S$ & $*$ & $*$ & $N S$ & $N S$ & $*$ & $*$ & $N S$ & $*$ & $N S$ & $*$ & $N S$ & $N S$ & $N S$ & $N S$ & $N S$ \\
\hline$B \times C$ & $N S$ & $*$ & $*$ & $N S$ & $N S$ & $*$ & $*$ & $N S$ & $N S$ & $N S$ & $N S$ & $N S$ & $N S$ & $N S$ & $N S$ & $*$ & $N S$ & $N S$ \\
\hline $\begin{array}{c}A \times B \times \\
C\end{array}$ & $*$ & $N S$ & $*$ & $N S$ & $*$ & $*$ & $*$ & $*$ & $N S$ & $N S$ & $N S$ & $N S$ & $N S$ & $*$ & $N S$ & $N S$ & $*$ & $N S$ \\
\hline
\end{tabular}

Table.3: Flag leaf area, plant height, stem diameter, number of tillers/plant, number of days to 50\% heading and number of days to 50\% flowering as affected by foliar spraying and nitrogen fertilizer levels of some wheat cultivars as well as their interactions during 2013/2014 and 2014/2015 seasons.

\begin{tabular}{|c|c|c|c|c|c|c|c|c|c|c|c|c|}
\hline \multirow[t]{2}{*}{$\begin{array}{l}\text { Characters } \\
\text { Treatments }\end{array}$} & \multicolumn{2}{|c|}{$\begin{array}{c}\text { Flag leaf area } \\
\left(\mathrm{cm}^{2}\right)\end{array}$} & \multicolumn{2}{|c|}{ Plant height (cm) } & \multicolumn{2}{|c|}{$\begin{array}{c}\text { Stem diameter } \\
(\mathrm{cm})\end{array}$} & \multicolumn{2}{|c|}{$\begin{array}{l}\text { Number of } \\
\text { tillers/plant }\end{array}$} & \multicolumn{2}{|c|}{$\begin{array}{c}\text { Number of days to } \\
50 \% \text { heading }\end{array}$} & \multicolumn{2}{|c|}{$\begin{array}{c}\text { Number of days to } \\
50 \% \text { flowering }\end{array}$} \\
\hline & $1^{s t}$ & $2^{\text {nd }}$ & $1^{s t}$ & $2^{n d}$ & $1^{s t}$ & $2^{n d}$ & $1^{s t}$ & $2^{n d}$ & $1^{s t}$ & $2^{n d}$ & $1^{s t}$ & $2^{n d}$ \\
\hline \multicolumn{13}{|l|}{ A-Cultivars: } \\
\hline Shaka 93 & 25.79 & 26.71 & 80.84 & 84.18 & 3.20 & 3.60 & 3.69 & 3.88 & 77.8 & 78.1 & 84.1 & 84.1 \\
\hline Gemiza 9 & 30.74 & 32.22 & 93.30 & 96.30 & 3.77 & 4.03 & 4.76 & 4.93 & 87.9 & 88.9 & 92.9 & 95.9 \\
\hline Giza 168 & 32.20 & 35.18 & 90.25 & 93.25 & 3.66 & 3.98 & 4.38 & 4.38 & 82.1 & 82.6 & 89.5 & 90.6 \\
\hline F. test & * & $*$ & * & * & $*$ & * & $*$ & $*$ & $*$ & $*$ & * & * \\
\hline LSD at $5 \%$ & 1.68 & 1.24 & 1.77 & 1.67 & 0.09 & 0.13 & 0.45 & 0.44 & 1.1 & 1.0 & 1.7 & 1.6 \\
\hline \multicolumn{13}{|c|}{ B-Foliar spraying: } \\
\hline $\begin{array}{c}\text { Control } \\
\text { treatment }\end{array}$ & 25.24 & 25.84 & 85.02 & 85.02 & 3.10 & 3.28 & 3.31 & 3.27 & 82.0 & 82.4 & 88.0 & 89.4 \\
\hline $\begin{array}{c}\text { Humic acid } \\
(\text { (HA) }\end{array}$ & 29.71 & 33.30 & 88.64 & 92.32 & 3.66 & 4.02 & 4.70 & 5.00 & 82.7 & 83.0 & 88.7 & 90.0 \\
\hline $\begin{array}{l}\text { Amino acids } \\
(A A)\end{array}$ & 30.55 & 31.73 & 87.45 & 91.97 & 3.51 & 3.84 & 4.33 & 4.25 & 82.8 & 83.2 & 88.8 & 90.2 \\
\hline $\begin{array}{c}\text { Mixture of } H A \\
+A A\end{array}$ & 32.82 & 34.59 & 91.42 & 95.66 & 3.90 & 4.33 & 4.77 & 5.07 & 83.0 & 84.3 & 89.9 & 91.3 \\
\hline F. test & $*$ & $*$ & $*$ & $*$ & $*$ & $*$ & $*$ & $*$ & $*$ & $*$ & $*$ & $*$ \\
\hline LSD at $5 \%$ & 1.77 & 1.26 & 0.80 & 0.97 & 0.12 & 0.19 & 0.53 & 0.79 & 0.6 & 0.5 & 0.8 & 0.6 \\
\hline \multicolumn{13}{|c|}{ C- Nitrogen fertilizer levels: } \\
\hline $166 \mathrm{~kg} \mathrm{~N} / \mathrm{ha}$ & 26.40 & 28.43 & 83.39 & 88.64 & 3.32 & 3.59 & 3.93 & 3.76 & 81.9 & 81.7 & 87.8 & 88.7 \\
\hline $214 \mathrm{~kg} \mathrm{~N} / \mathrm{ha}$ & 29.36 & 31.08 & 88.82 & 91.09 & 3.51 & 3.87 & 4.36 & 4.47 & 82.5 & 83.4 & 89.0 & 90.4 \\
\hline $262 \mathrm{~kg} \mathrm{~N} / \mathrm{ha}$ & 32.98 & 34.59 & 92.18 & 94.00 & 3.79 & 4.14 & 4.55 & 4.97 & 83.4 & 84.6 & 89.8 & 91.6 \\
\hline F. test & $*$ & $*$ & $*$ & * & * & $*$ & $*$ & $*$ & * & * & * & $*$ \\
\hline LSD at $5 \%$ & 0.72 & 0.80 & 0.63 & 0.56 & 0.09 & 0.09 & 0.35 & 0.24 & 1.0 & 0.7 & 0.6 & 0.5 \\
\hline \multicolumn{13}{|l|}{ D- Interactions: } \\
\hline$A \times B$ & $N S$ & $N S$ & $*$ & $*$ & $N S$ & $*$ & $N S$ & $N S$ & $N S$ & $N S$ & $N S$ & $N S$ \\
\hline$A \times C$ & $*$ & $\overline{N S}$ & $*$ & $\overline{N S}$ & $N S$ & $\overline{N S}$ & $\overline{N S}$ & $*$ & $\overline{N S}$ & * & $N S$ & $*$ \\
\hline $\boldsymbol{B} \times \boldsymbol{C}$ & $N S$ & $*$ & $*$ & $*$ & $*$ & $N S$ & $*$ & $N S$ & $N S$ & $N S$ & $*$ & $N S$ \\
\hline$A \times B \times C$ & $*$ & $N S$ & $*$ & $N S$ & $*$ & $N S$ & $*$ & $N S$ & $N S$ & $N S$ & $*$ & $N S$ \\
\hline
\end{tabular}




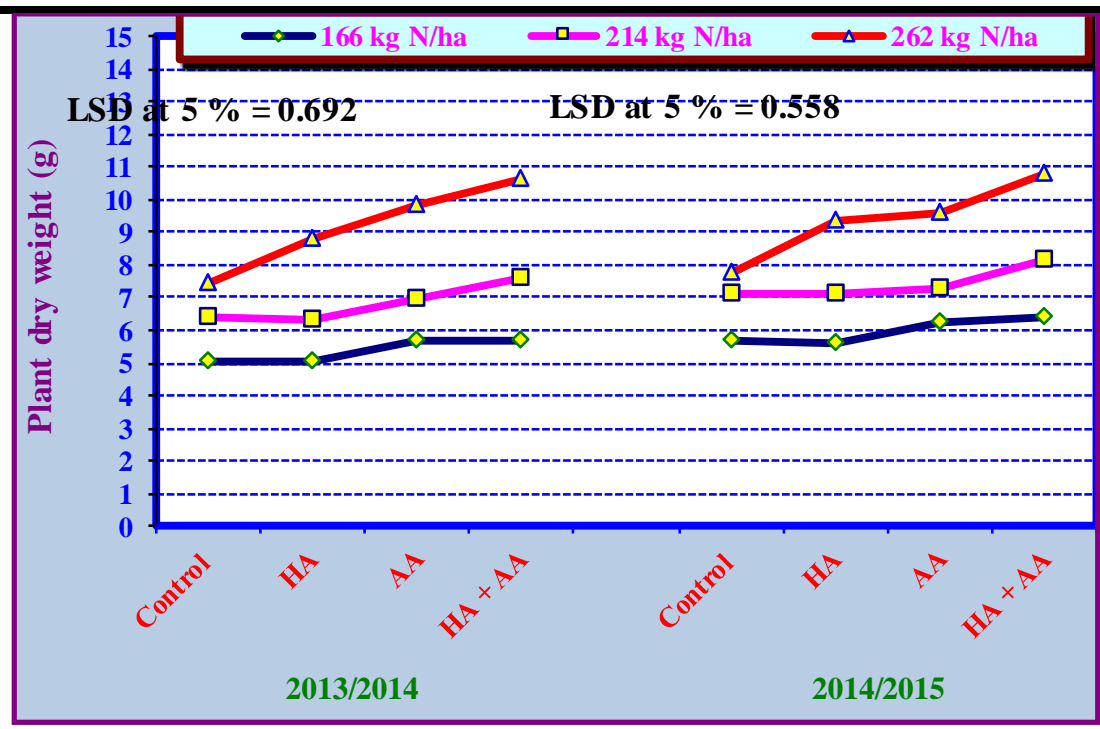

Fig. 1: Plant dry weight $(\mathrm{g})$ after 75 DFS as affected by the interaction between foliar spraying and nitrogen fertilizer leve ls during 2013/2014 and 2014/2015 seasons.

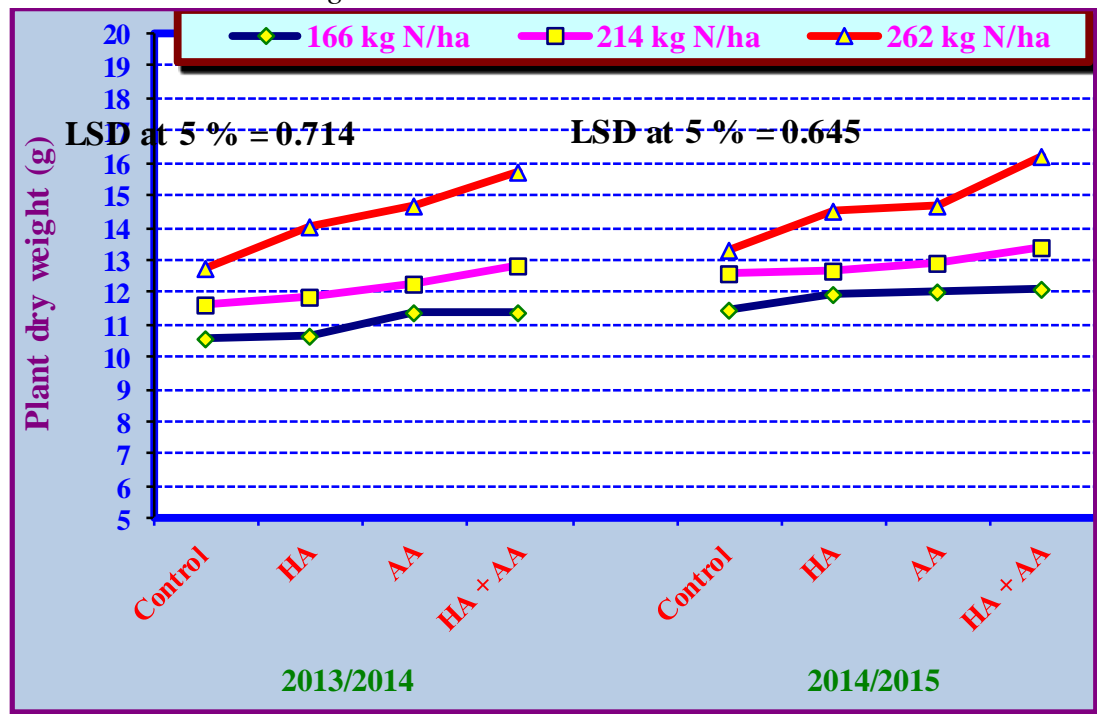

Fig. 2: Plant dry weight $(\mathrm{g})$ after 95 DFS as affected by the interaction between foliar spraying and nitrogen fertilizer levels during 2013/2014 and 2014/2015 seasons.

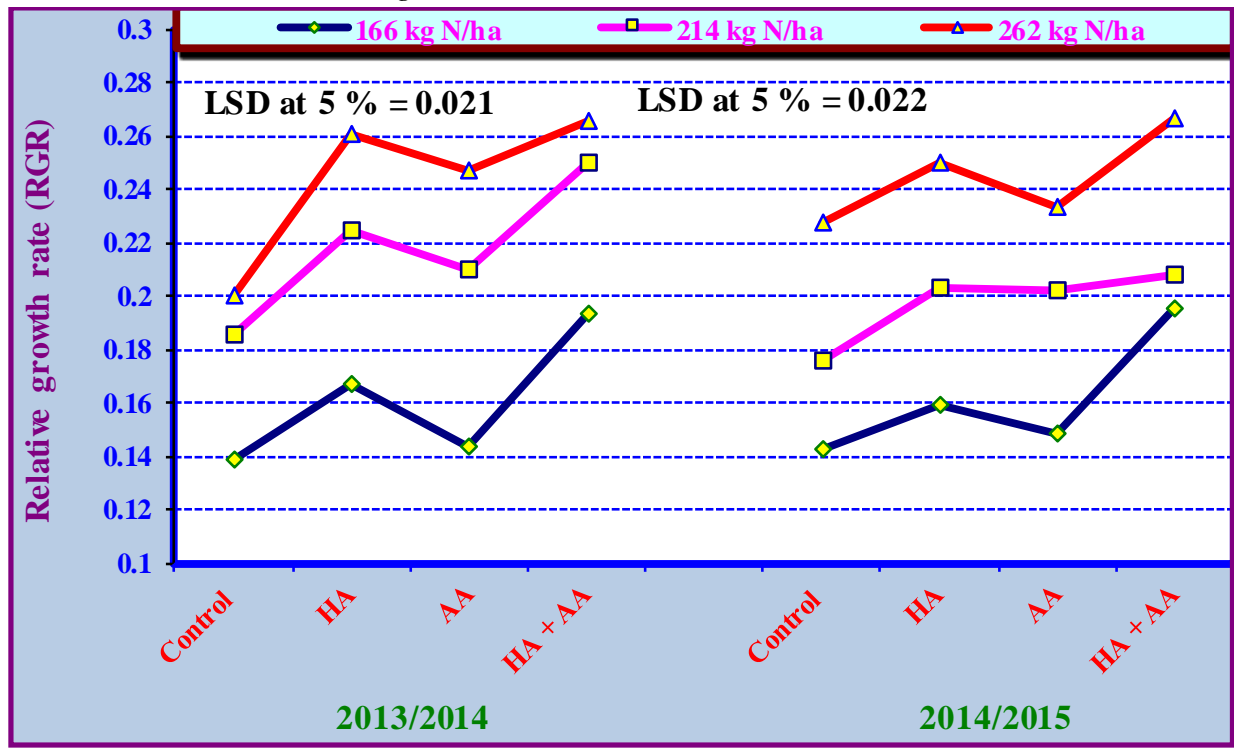

Fig. 3: Relative growth rate (RGR) as affected by the interaction between foliar spraying and nitrogen fertilizer levels during 2013/2014 and 2014/2015 seasons. 


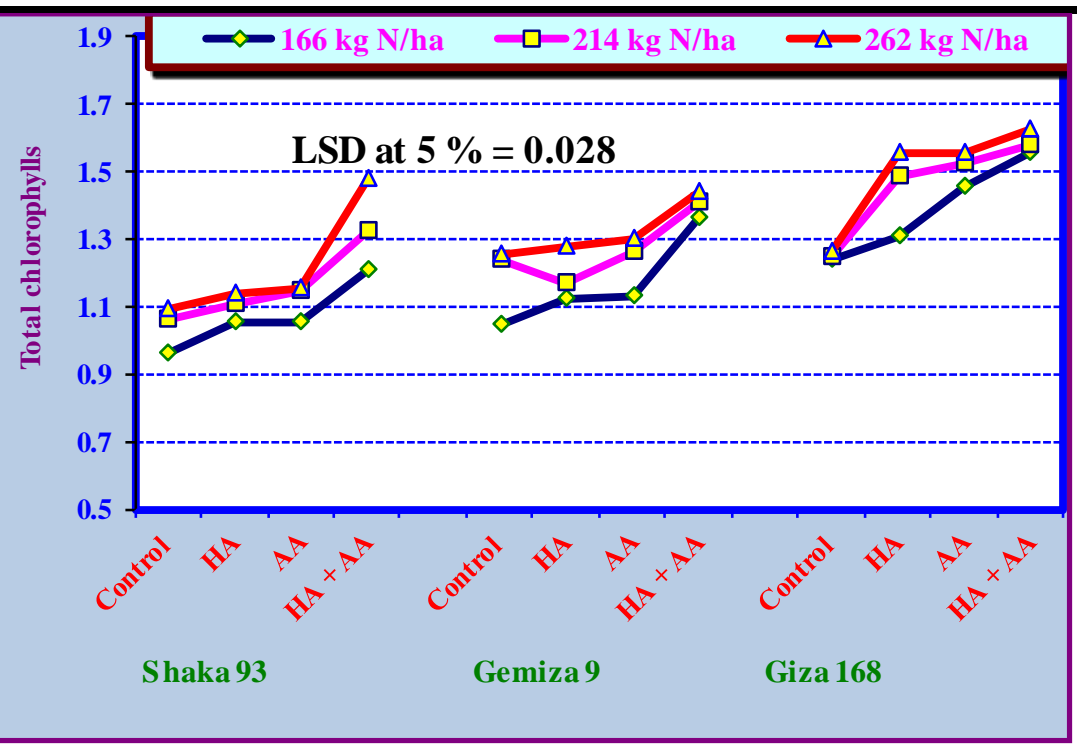

Fig. 4: Total chlorophylls content as affected by the interaction among wheat cultivars, foliar spraying and nitrogen fertilizer levels during 2013/2014 season.

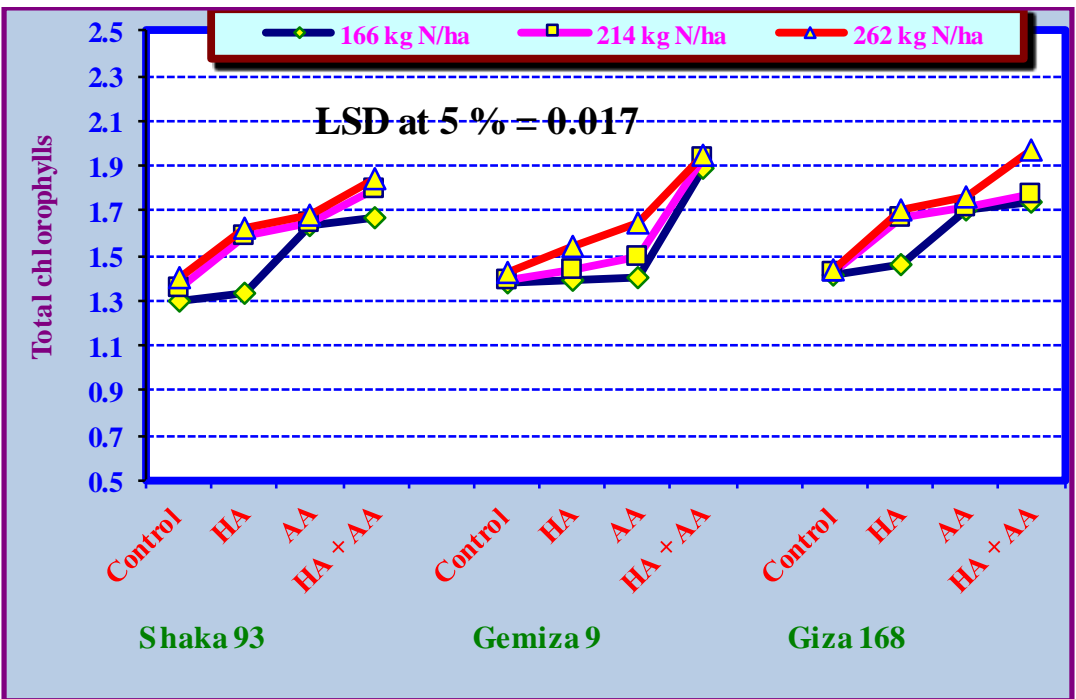

Fig. 5: Total chlorophylls content as affected by the interaction among wheat cultivars, foliar spraying and nitrogen fertilizer levels during 2014/2015 season.

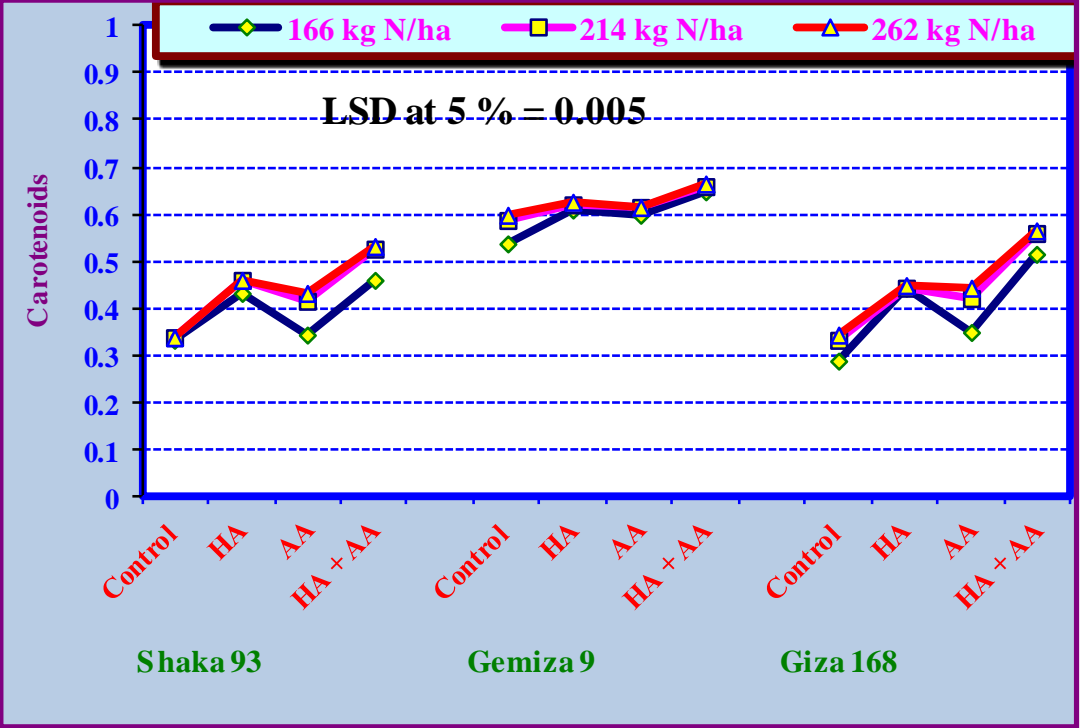

Fig. 6: Carotenoids content as affected by the interaction among wheat cultivars, foliar spraying and nitrogen fertilizer levels during 2013/2014 season. 


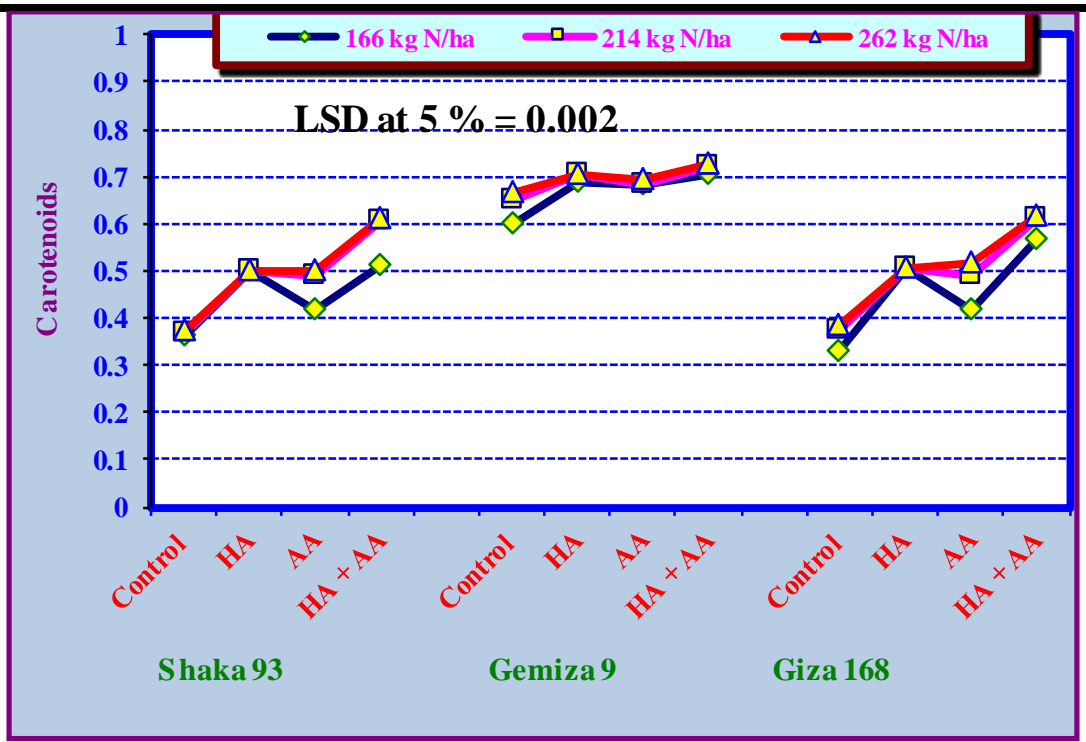

Fig. 7: Carotenoids content as affected by the interaction among wheat cultivars, foliar spraying and nitrogen fertilizer levels during 2014/2015 season.

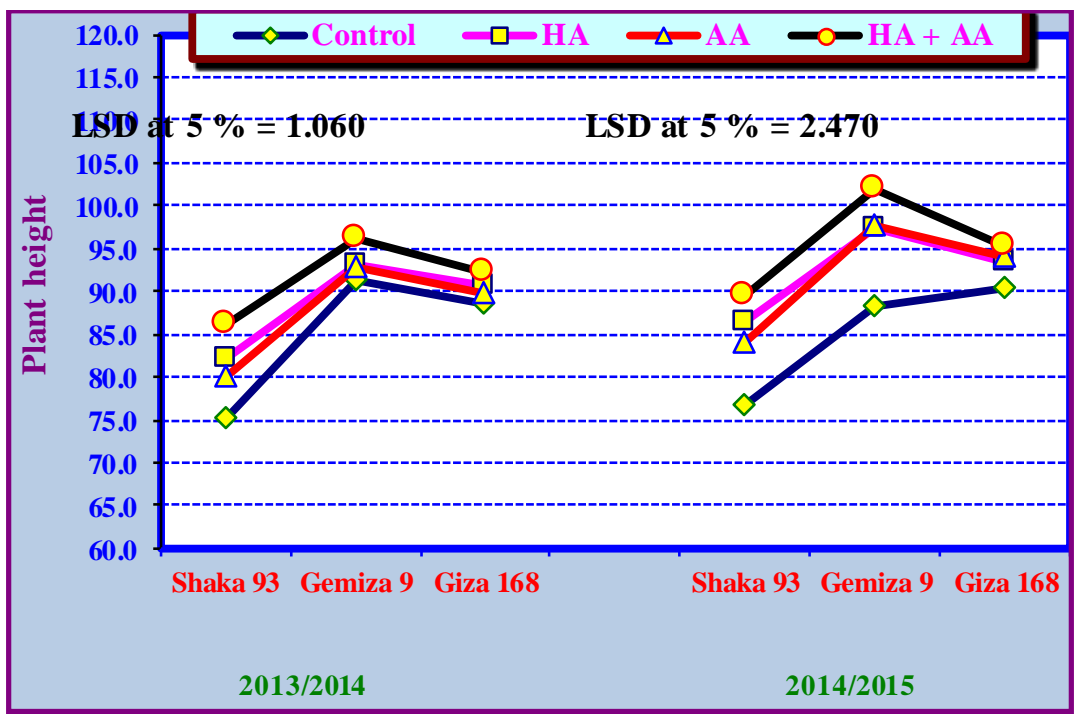

Fig. 8: Plant height as affected by the interaction between wheat cultivars and foliar spraying during 2013/2014 and 2014/2015 seasons.

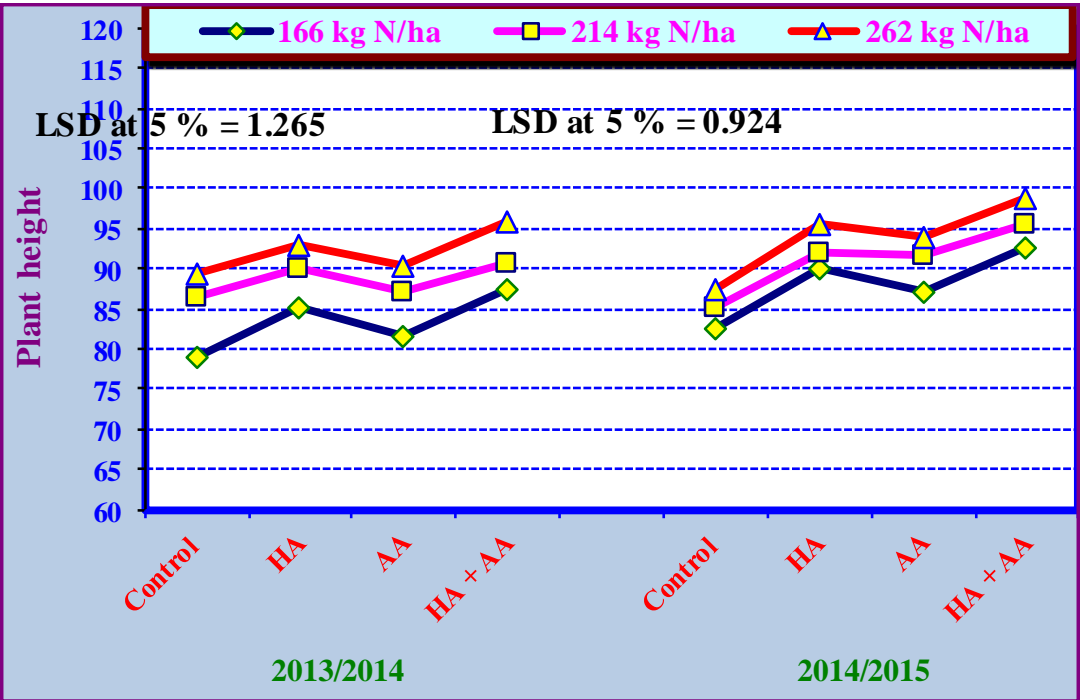

Fig. 9: Plant height area as affected by the interaction between foliar spraying and nitrogen fertilizer levels during 2013/2014 and 2014/2015 seasons. 